1915, in Montreal. Both parents were American citizens; and both distinguished themselves in American public service organizations, in particular in the Unitarian Service Committee and in its work with refugees during the Second World War. Dexter's father came of a family long established in Nova Scotia as shipbuilders and ship captains. These roots pulled Dexter back, in his sixties and seventies, to Nova Scotia for a long sojourn every year, in Halifax and as a Visiting Fellow in Public Administration at Dalhousie. However, his descent through his mother from a long line of New England ministers and millowners was equally important to him; and his sense of American politics was strongly colored, on the one side by the history of his family and the region, on the other, by extensive reading of British history and literature. He applied to the study and teaching of politics not only Lord Halifax, but also Sir Walter Scott and Anthony Trollope.

Dexter earned his Bachelor's degree in 1935 after 15 months' study at the University of Chicago, setting a speed record. Proceeding to Harvard, he became for a time a student of Carl Friedrich. Riesman, a fellow student then, was deeply impressed by Dexter's Chicago record, but now says, "I later came to feel that this was not an unmixed blessing, perhaps depriving him of the opportunity to cultivate more of the amenities of life while still engaged in understanding the paradoxes."

After taking in 1938 an interdisciplinary M.A. at Harvard with a thesis on "Anthropological Theories of Imperialism," Dexter plunged directly into his career. Only much later, at the urging of friends, did he take his Ph.D.-at Columbia (1960), in sociology. When he first came to Dalhousie a decade later, he posted a notice on his office door deprecating his weakness in seeking this academic credential and citing William James on the "Ph.D. Octopus."

A substantial part of Dexter's career was spent in practical politics. He served as a consultant in many campaigns - for example, the primary campaigns for Stevenson in 1956, and John Volpe's campaign for Governor of Massachusetts in 1960 . He served as an advisor to governors, most notably in Puerto Rico, where he became a lifelong admirer of Luis Muñoz, and in Massachusetts, where he learned, among other things, how the mental hospital system could be used for costless political favors. (If patients' families wanted the patients in Boston for ease of visiting, that could be arranged; but if the families wanted the patients too far away for frequent visiting, they could be sent to hospitals elsewhere in the state.)

Of his career, Dexter himself once said, "The most important thing ... is that $I$ have always ... tried to be a generalist, but a generalist who is professionally competent at what he undertakes ... it is not surprising that my best article on Congress appeared in the journal of the Society for Applied Anthropology." He was not just competent; he was relentlessly inventive and deliberately counterfashionable. He once pointed out, in a letter to the APSR, that his article challenging the conventional wisdom about the virtue of oneman-one-vote was rejected by 14 journals before finding a respectable home in a volume of Nomos (1968). (Bringing together personal political experience and personal observation in Belmont, Massachusetts, it was unexpected, powerful, elegant and deep.) In his last years, he produced work containing illuminating reflections on the topics of corruption and "scandalization."

Dexter was a very unorthodox person who made an unorthodox career, which in every sense was extraordinarily fruitful, not least in the challenges that he posed other people, and in the affection and enthusiasm for which many of them, thus challenged, will remember him.

David Braybrooke

Dalhousie University \&

The University of Texas at Austin

Herbert A. Simon

Carnegie Mellon University

\section{Phillip Monypenny}

Phillip Monypenny, an academic pioneer in the field of public administration at the University of Illinois who vigorously campaigned for justice-and jobs - especially for minority students, died June 4 at Loyola University Medical Center in Maywood at the age of 81 .

Colleagues at Illinois credit Monypenny for the success of the Master of Arts degree program in public administration at the university, and for preparing scores of students who now are leaders in the field across the country. Former students remember Monypenny as a man whose "care and concern for students outweighed any numerical listing of his own accomplishments," said Sister Marie Golla, a University of Illinois academic adviser who was a friend of Monypenny for 27 years.

Golla said Monypenny's minority students considered the professor "the one person" to whom they could turn at a time when many of them felt unwelcome in academia.

"Undergraduates most remember him as a caring, kind, compassionate individual who was willing to be their mentor and help them pursue interests through independent study programs and internships in federal, state and local government," Golla said, adding that Monypenny continued his association with his former students throughout his life.

Monypenny's résumé includes a listing of several dozen students whom he counseled from their dissertations and doctoral degrees to their jobs.

Monypenny was a member of the University of Illinois political science department from 1947 to 1984 , serving as head from 1967 to 1972 , and held a joint appointment in the university's Institute of Government and Public Affairs from 1967 to his retirement.

Monypenny was born on Jan. 23, 1914 , in Montreal, and moved to the United States in 1921. Monypenny earned his bachelor's and master's degrees in 1936 and 1937 at Washington University, and his doctorate in political science and 
economics from the University of Minnesota in 1942.

Before joining the University of Illinois faculty, Monypenny was employed by the City College of New York. Following service in the U.S. Army from 1943 to 1946, first in Europe with an anti-aircraft battalion and later as an interrogator with an intelligence unit, Monypenny taught government at the University of Puerto Rico.

Monypenny married his wife, Helen, in 1940 in St. Louis, where they met while attending Washington University. She survives. He also is survived by twin daughters: Alice Monypenny of Park Forest and Laura Monypenny of Berwyn.

Monypenny was editor of the Midwest Journal of Political Science and an editorial board member of the Public Administration Review.

There were no funeral services; a memorial service is to be held later. Memorial contributions may be made to the University of Illinois Foundation in the name of the Phillip Monypenny Scholarship Fund.

Andrea Lynn

University of Illinois at

Urbana-Champaign

\section{Howard R. Penniman}

Howard R. Penniman, 79, died on April 13, 1995, at the Rockville (MD) Nursing Home. He had Alzheimer's disease.

Howard was renowned principally for his 25-year tenure as professor of government at Georgetown University, 1968-1983, but he pursued notable careers both in teaching and scholarship and in public affairs. At the center of both was the role of political parties and electoral systems among the principal institutions of democratic governments. His revised edition of Sait's American Parties and Elections, a classic in the field, was for two decades a widely used college textbook.

This also was the focus of a personal friendship that began, for me, in 1946 in his undergraduate classrooms at Yale University. In 1967,
Howard was named by President Lyndon B. Johnson-along with Don Herzberg and Dick Scammon-as academic adviser to the U.S. Commission to observe that year's presidential election in South Vietnam, which set the pattern for scores of similar observer missions in Latin America, Africa, and Asia. Howard himself took part in such official teams in the Occupied Territories of the West Bank (19791980), Rhodesia/Zimbabwe (19791980), Guatemala (1984), and the Philippines (1986).

In the same span of years, Howard initiated and was general editor of At the Polls, under the aegis of the American Enterprise Institute for Public Policy Research -where he was resident and later adjunct scholar-a multivolume series on elections and voting behavior in virtually every one of the world's democracies. He drew on his experience of the ' 67 Vietnam election and his monitoring of several subsequent political campaigns in that country to publish a comprehensive study, Elections in South Vietnam, in 1973. Beginning in 1968, Howard was an elections consultant to $\mathrm{ABC}$ and, for some 20 years, helped design and implement that national network's election night coverage of presidential, congressional, and gubernatorial campaigns.

He served in the U.S. Army during the Second World War. After the war, he held a number of positions in the newly-created national security establishment: in CIA, the State Department's external research staff, the Psychological Strategy Board, and the U.S. Information Agency, where he was instrumental in building "libraries of the classics of democracy" at USIS offices within the Soviet bloc and throughout the Third World. He was an elected delegate to the Maryland Constitutional Convention in 1967-1968 and was chairman of its Committee on Style, Drafting, and Arrangements. He was co-chairman of the Montgomery County (MD) School System's Committee for the Study of Drug Abuse and served for two terms, by appointment of the governor, as a trustee of the Montgomery (MD) College, 1972-1981.

Howard was born in Steger, IL, and received his B.A. and M.S. degrees from Louisiana State University and his Ph.D. from the University of Minnesota, where he also married the boss's daughter. His wife of 54 years was the former Morgia Anderson, better known as Betty, whose father was the eminent political scientist, William "Pops" Anderson, a past president of the American Political Science Association. Howard taught at the University of Alabama as well as at Yale and Georgetown.

Howard was active in several programs of the national office of the American Political Science Association: director of the Congressional Fellowship Program, 19581959; director of regional seminars for political scientists from small colleges in the 1960s; and director of seminars for reporters of public affairs, 1957-1972. He was a former president of the National Capital Area Political Science Association, 1958-1959, and received its $\mathrm{Pi}$ Sigma Alpha Award in 1988. He served also as president of the $\mathrm{Na}$ tional Political Science Honor Society for which the award is named, and as its longtime national director.

He was a board member of the American Peace Society and editorial adviser to its quarterly, World Affairs. He was a trustee of the Helen Dwight Reid Educational Foundation, the publisher of 44 professional journals.

Howard is survived also by two sons, William H. of McLean, VA, and Matthew F. of Dayton, MD; three daughters, Barbara J. Cayelli of Rockville, MD, Ruth M. Martin of Baltimore, MD, and Catherine C. Hellerman of Silver Spring, MD; by 19 grandchildren; and by a sister, Clara Penniman of Madison, WI, herself a noted political science teacher and scholar at the University of Wisconsin.

My own vivid memories of Howard, all of them of a warm and loyal friend, run a very wide gamut: literally hundreds of stimulating (and often contentious) lunch- and dinner-table conversations; dozens of wine-tasting evenings with those of his and Betty's closest circle 